\title{
Adjustment of nonlinear models and growth parameters and body nutrient deposition in meat-type and laying quail
}

\section{Daiane de Oliveira Grieser ${ }^{1 *}$ (iD, Simara Márcia Marcato ${ }^{1}$, Antonio Claudio Furlan ${ }^{1}$, Vittor Zancanela² (iD, Eliane Gasparino', Ana Paula Del Vesco², Nayara Cristine Freitas Lima1, Paulo Cesar Pozza ${ }^{1}$}

\footnotetext{
${ }^{1}$ Universidade Estadual de Maringá, Departamento de Zootecnia, Maringá, PR, Brasil.

${ }^{2}$ Universidade Federal de Sergipe, Departamento de Zootecnia, Aracaju, SE, Brasil.
}

\begin{abstract}
The objective of this study was to determine the adjustment quality of non-linear models and estimate the growth parameters and body chemical composition of a meat-type quail strain (Coturnix coturnix coturnix) and two laying quail strains (Coturnix coturnix japonica), designated yellow and red. The study used 1500 quail, not sexed, distributed in a completely randomized design with three treatments and five repetitions. The experimental period was from 1-42 days of age. The birds were raised in a conventional system and fed ad libitum with a diet formulated to meet their nutritional requirements. Quail were weighed weekly, and a representative sample was slaughtered to evaluate their body chemical composition. The adjustment quality of the models was evaluated by means of the residual mean square (RMS), regression residue squares sum (SSRR), and number of iterations required for convergence. In evaluating the adjustment quality for the body weight of the three strains, the Gompertz, Logistic, and Von Bertalanffy models gave good fit, with Gompertz providing the best adjustment among them. For body composition, the Gompertz and Logistic models were the best, with Gompertz showing a slight superiority. Gompertz is the best model for describing growth curves and body chemical composition of body weight, protein, water, and ash in meat-type quail. In addition, it is the best model for describing growth curves and body chemical composition of body weight of yellow laying quail and of body weight, protein, and ash in red laying quail. Logistic was the best model for describing growth curves and body chemical composition of water, protein, and ash in yellow laying quail, and of water in red laying quail.
\end{abstract}

Key Words: body chemical deposition, Gompertz curve, iterations, residual mean square, square sum of the regression residual

\section{Introduction}

Coturniculture has been gaining market share both nationally and internationally, as an activity that requires low investment, with rapid financial return, involving birds that are easy to handle, have early sexual maturity, and are highly productive. The most commonly used strains in Brazil for commercial egg and meat production are the Japanese (Coturnix coturnix japonica) and the European (Coturnix coturnix coturnix) quail, respectively (Barreto et al., 2007).

Japanese quail are the most widespread in Brazil and in the world, being distinguished by their high egg production, fast growth, small size, early sexual maturity, and average weight at 42 days of age between 130 and

Received: September 26, 2017

Accepted: June 28, 2018

*Corresponding author: daianegrieser@gmail.com

Copyright (C) 2018 Sociedade Brasileira de Zootecnia. This is an Open Access article distributed under the terms of the Creative Commons Attribution License (http://creativecommons.org/licenses/by/4.0/), which permits unrestricted use, distribution, and reproduction in any medium, provided the original work is properly cited.
$140 \mathrm{~g}$. The European quail, which are larger, are used for meat production, presenting a high growth rate and an average weight of $250 \mathrm{~g}$ at 42 days of age. Both meat and laying quail are good alternatives for generating income and obtaining quality products (Grieser et al., 2015a).

Quail genetics are continuously improving, allowing the selection of the best birds, with the best potential to increase productivity rates. Therefore, due to the constant genetic improvement applied to quail populations, there have been great changes in the growth and body chemical deposition characteristics of the strains available in the market, making it necessary to carry out research that allows the elaboration of growth models for these current strains (Marcato et al., 2010).

Several non-linear mathematical models have been used to describe the growth and body chemical deposition of animals (Logistic, Brody, Richards, Bertalanffy, and Gompertz), by estimating the parameters for a certain variable. To make this adjustment, there are differences between the models regarding the difficulties faced in data processing, biological interpretation of the results 
obtained, and quality of adjustment of the models to the data. Therefore, it is necessary to carry out an evaluation of the models using predetermined criteria and select the model with the best potential to describe the growth of the animals (Fitzhugh Jr., 1976). However, among the nonlinear models, Gompertz has been the most used to describe the growth of birds, because it presents a better adjustment (Marcato et al., 2010; Narinc et al., 2010; Sakomura et al., 2011; Finco et al., 2016; Rossi et al., 2017).

These mathematical models allow the analysis of animal development and the adoption of strategies to improve management and nutrition. The growth of the animals is intimately related to their nutritional requirements; the greater the daily weight gain, the greater the nutritional requirements; thus, the nutritional requirements need to stabilize when weight at maturity is reached. In addition, it is also possible to add other important factors to these models, for example, to correlate the thermal factors with the growth and body chemical deposition of birds, contributing to better welfare in breeding systems and to obtain better productive responses. These data can also be used by genetic breeding programs, allowing the selection of more efficient birds, heat- and disease-resistant, and more uniform batches (Marcato et al., 2010; Sakomura et al., 2011).

Based on this information, the objective of this work was to determine the quality of adjustment of nonlinear models and estimate the growth parameters and body chemical composition of one strain of meat-type quail (Coturnix coturnix coturnix) and two laying strains (Coturnix coturnix japonica), designated yellow and red.

\section{Material and Methods}

This study was approved by the ethics committee on the use of animals (CEUA) (case no. 061/2012).

A total of 1,500 non-sexed quail at one day old were taken and ringed with numbered washers, allowing the collection of individual data. Of the total, 500 were of the meat-type quail strain (Coturnix coturnix coturnix), 500 of the yellow laying strain (Coturnix coturnix japonica), and 500 of the red laying strain (Coturnix coturnix japonica). The yellow and red laying strains were developed by the animal genetic improvement program.

Quail were raised in a conventional shed, divided into 15 boxes of $5.0 \mathrm{~m}^{2}$, and each box was considered as a repetition or experimental unit. Birds were distributed in the boxes using a completely randomized design, with a total of three treatments (each treatment corresponded to one strain of quail), five replicates, and 100 quail per replicate. The experimental period was from 1 to 42 days of age.

Throughout the experimental period, quail were raised in a conventional breeding system, receiving feed and water ad libitum. The light program used was the ideal regime for the development of each lineage, with continuous light being provided for the meat-type quail, and the laying quail being provided with $22 \mathrm{~h}$ of light/day from 1 to 14 days of age and $12 \mathrm{~h}$ of light/day from 15 to 42 days of age.

The rations were formulated based on corn and soybean meal, considering the values of chemical and energetic composition of feeds proposed by Rostagno et al. (2017), meeting the nutritional requirements of quail according to their lineage and growth phase (Table 1).

To determine body growth, the methodology described by Sakomura and Rostagno (2016) was used. The weight was individually monitored (birds being identified with numbered rings) and weighed weekly on a precision scale.

Table 1 - Centesimal, chemical, and energetic composition of diets for meat-type quail at initial and final growth phases and for laying quail (yellow and red)

\begin{tabular}{|c|c|c|c|}
\hline & \multicolumn{2}{|c|}{ Meat-type quail } & \multirow{2}{*}{$\begin{array}{c}\begin{array}{c}\text { Laying } \\
\text { quail }\end{array} \\
1-42 \text { days }\end{array}$} \\
\hline & 1-14 days & 15-42 days & \\
\hline Ingredient & \multicolumn{3}{|c|}{ Quantity (g/kg) } \\
\hline Corn & 409.5 & 527.9 & 571.6 \\
\hline Soybean meal (45\%) & 497.4 & 393.1 & 380.5 \\
\hline Soybean oil & 47.5 & 32.5 & 11.0 \\
\hline Dicalcium phosphate & 15.6 & 16.0 & 14.1 \\
\hline Salt & 4.6 & 4.6 & 3.9 \\
\hline Limestone & 3.6 & 2.8 & 11.6 \\
\hline DL-methionine & 6.7 & 6.6 & 1.9 \\
\hline $\mathrm{L}$ - lysine $\mathrm{HCl}$ & 6.8 & 8.0 & 0.5 \\
\hline L-threonine & 4.2 & 4.1 & 0.9 \\
\hline L-tryptophan & 0.1 & 0.4 & - \\
\hline Vitamin and mineral mixture ${ }^{1}$ & 4.0 & 4.0 & 4.0 \\
\hline \multicolumn{4}{|l|}{ Calculated values } \\
\hline Metabolizable energy (MJ/kg) & 12.54 & 12.70 & 12.15 \\
\hline Crude protein $(\mathrm{g} / \mathrm{kg})$ & 275 & 235 & 220 \\
\hline Calcium (g/kg) & 6.4 & 6.1 & 9.0 \\
\hline Available phosphorus (g/kg) & 4.1 & 4.1 & 3.7 \\
\hline Sodium $(\mathrm{g} / \mathrm{kg})$ & 2.0 & 2.0 & 1.8 \\
\hline Potassium (g/kg) & 10.2 & 8.6 & - \\
\hline Chlorine $(\mathrm{g} / \mathrm{kg})$ & 3.1 & 3.1 & - \\
\hline $\begin{array}{l}\text { Methionine }+ \text { digestible cystine } \\
(\mathrm{g} / \mathrm{kg})\end{array}$ & 13.2 & 12.3 & 7.6 \\
\hline Digestible lysine $(\mathrm{g} / \mathrm{kg})$ & 18.7 & 17.3 & 11.2 \\
\hline Digestible threonine $(\mathrm{g} / \mathrm{kg})$ & 12.5 & 11.1 & 7.9 \\
\hline Digestible tryptophan (g/kg) & 3.0 & 2.8 & - \\
\hline
\end{tabular}

${ }^{1}$ Vitamin/mineral supplementation (guaranteed levels per kilogram of diet): retino acetate, 18,000 IU; cholecalciferol, $5000 \mathrm{IU}$; dl- $\alpha$-tocopheryl acetate, $16 \mathrm{mg}$; thiamine hydrochloride, $1.12 \mathrm{mg}$; riboflavina, $8 \mathrm{mg}$; pyridoxine hydrochloride, $2.1 \mathrm{mg}$; cyanocobalamin, $20 \mathrm{mcg}$; menadione nicotinamide bisulphite, $4.028 \mathrm{mg}$; D-calcium pantothenate, $16 \mathrm{mg}$; niacin acid, $40 \mathrm{mg}$; choline chloride, $560 \mathrm{mg}$; zinc oxide, $126 \mathrm{mg}$; ferrous sulphate, $98 \mathrm{mg}$; manganese sulphate, $155 \mathrm{mg}$; copper sulphate, $30.624 \mathrm{mg}$; cobaltous sulfate heptahydrate, $0.4 \mathrm{mg}$; potassium iodate $1.936 \mathrm{mg}$; sodium selenite, $0.508 \mathrm{mg}$; butylated hydroxytoluene, $0.02 \mathrm{mg}$. 
This process allowed quail growth curves of the different strains to be obtained in the period from 1 to 42 days of age.

To determine the chemical composition of nutrients in quail carcass, the methodology described by Sakomura and Rostagno (2016), was used. Quail were slaughtered at $1,7,14,21,28,35$, and 42 days of age, a total of 30 , $15,8,5,4,3$, and 2 quail per replicate, respectively. Before being slaughtered, they were selected according to the mean weight $( \pm 5 \%)$ of each experimental unit and subjected to $6 \mathrm{~h}$ of fasting to the complete emptying of the contents of the gastrointestinal tract. The birds were then weighed, slaughtered, and frozen whole. Afterwards they were thawed, ground, homogenized, and pre-dried in an oven. Then, the samples were ground again and sent to the laboratory to obtain analytical determinations - dry matter (DM), crude protein (CP), fat, and ash - following the methodologies described by AOAC (2005).

Using the values for body weights and chemical composition, growth curves and body chemical deposition were estimated through SAS (Statistical Analysis System, version 9.4) using the following non-linear models: Gompertz (Fialho, 1999), A.e $\mathrm{e}^{-\mathrm{e}-\mathrm{B}(\mathrm{t}-\mathrm{C})}$; Brody (Brody, 1945), A $\left(1-\mathrm{Be}^{-\mathrm{kt}}\right)$; Von Bertalanffy (Von Bertalanffy, 1957), $\mathrm{A}\left(1-\mathrm{Be}^{-\mathrm{kt}}\right)^{3}$; Logistic (Nelder, 1961), A $\left(1+\mathrm{Be}^{-\mathrm{kt}}\right)^{-1}$; and Richards (Richards, 1959), A $\left(1-\mathrm{Be}^{-\mathrm{kt}}\right)^{\mathrm{M}}$, in which, in all models, parameter $\mathrm{A}$ is the weight at maturity $(\mathrm{g}), \mathrm{k}$ is the maturity rate $\left(\right.$ day $\left.^{-1}\right)$, and $\mathrm{B}$ is a constant of integration without biological interpretation, except in Gompertz, in which it has a biological interpretation representing the relative growth at the inflection point ( $\mathrm{g}$ /day per $\mathrm{g}$ ). Parameters $\mathrm{M}$ and $\mathrm{C}$ represent the age (days) of the inflection point of the growth curve and e is the Napierian logarithm. In addition, the models have the following variables: Brody, $\mathrm{m}=1$ (g/day); von Bertalanffy, $\mathrm{m}=3$ (g/day); Logistic, $\mathrm{m}=-1$ ( $\mathrm{g} /$ day); and Richards, $\mathrm{m}$ is variable.

Parameters k (for Brody, von Bertalanffy, Logistic, and Richards) and B (for the Gompertz model), are the growth rates of the animal; the higher the value of this rate, the faster is the growth of the animals, reducing the time taken to reach the adult weight (Carneiro et al., 2014). Parameter $\mathrm{C}$ in the Gompertz model is the age of the animal when the maximum growth rate indicates in the inflection point of the growth curve, in which body weight gain goes from increasing to decreasing (Freitas, 2005).

To choose the most appropriate model, the adjustment quality for the data was assessed by considering the following criteria: the computational difficulties (number of iterations required for convergence of functions) and adjustment quality the data [residual mean square (RMS) and square sum of the regression residual (SSRR)]. Higher numbers of iterations and higher values of RMS and SSRR indicate a lower adjustment quality for the non-linear model, suggesting its unsuitability for describing the growth of the animals.

\section{Results}

All the models analyzed adjusted to the data for body weight of the three strains of quail evaluated, but differed in adjustment quality.

In general, Gompertz was the best model for describing growth curves in body weight in meat-type and laying quail strains (Figure 1a). The Gompertz and Von Bertalanffy models presented better adjustments for body weight in meat-type quail, with lower respective numbers of iterations (16 and 8) and values for RMS (426.10 and 426.70) and SSRR (65198300 and 65290000).

In meat-type quail, in the parameter estimation using the five models, Von Bertalanffy gave the highest estimate of parameter A for body weight, which means weight at maturity, with a value of $347.6 \mathrm{~g}$. It was followed by Gompertz, with a value of $309.3 \mathrm{~g}$. The Brody and Richards models gave non-significant estimates. Parameter B for Gompertz and parameter $\mathrm{K}$ for the other models represent maturity rate. The Logistic model gave the highest estimate of the maturity rate for body weight $(0.131)$, followed by Gompertz (0.071). Parameter C of Gompertz shows the day when growth rate is maximal; thus, the age at the inflection point of the curve for body weight was 18.5 days of age (Figure 1b).

The Gompertz and Logistic models gave the best adjustment in yellow laying quail for body weight data, with lower values of RMS and SSRR. The Gompertz values were slightly smaller than those of Logistic, even though the number of iterations was larger for Gompertz (16) than for the Logistic model (7). Gompertz presented the best adjustment for this variable, taking into account the SSRR.

For body weight of the yellow laying quail, the highest value of parameter A was produced by Von Bertalanffy, with a value of $190.0 \mathrm{~g}$, followed by Gompertz with $169.0 \mathrm{~g}$, and Logistic with $147.0 \mathrm{~g}$. Richards and Brody presented decreasing values for this same parameter. However, the result that should be considered for weight at maturity is that of Gompertz, of $169.0 \mathrm{~g}$, because it was the model that was best adjusted to the data for body weight.

The inflection points of growth rate curves, as described by the Gompertz model that presented good adjustments, was 17.9 days of age for the variable body weight in yellow quail (Figure 1b). 
For body weight of red laying quail (Table 2), the best models were Gompertz and Von Bertalanffy, with the lowest respective numbers of iterations (16 and 9), RMS (136.90 and 138.50), and SSRR (156755.00 and 158556.00).

Von Bertalanffy gave the highest estimate of parameter A for body weight (174.6 g) for red laying quail, followed by the Gompertz (155.7 g) and Logistic models (135.7 g),

(a)

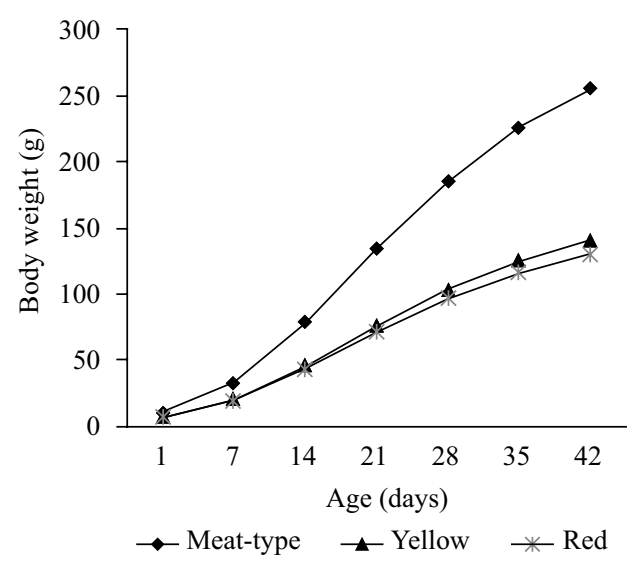

but the estimated value for Gompertz was more accurate because of its adjustment to the data. Gompertz presented value of 17.5 days of age at which the growth rate was maximum for the variable body weight (Figure 1b). The Richards model converged when subjected to the data, but the adjustment was not adequate, verified by the high values of RMS and SSRR in comparison with the other models, overestimating the estimates obtained. (b)

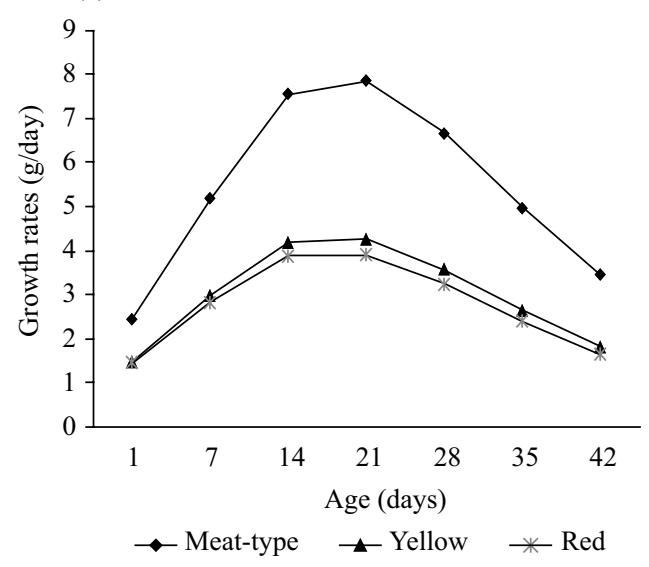

Figure 1 - Growth curves (a) and growth rates (b) of body weight in meat-type and laying quail (yellow or red).

Table 2 - Estimated values of non-linear model parameters for body weight in one meat-type and two laying quail strains (yellow and red)

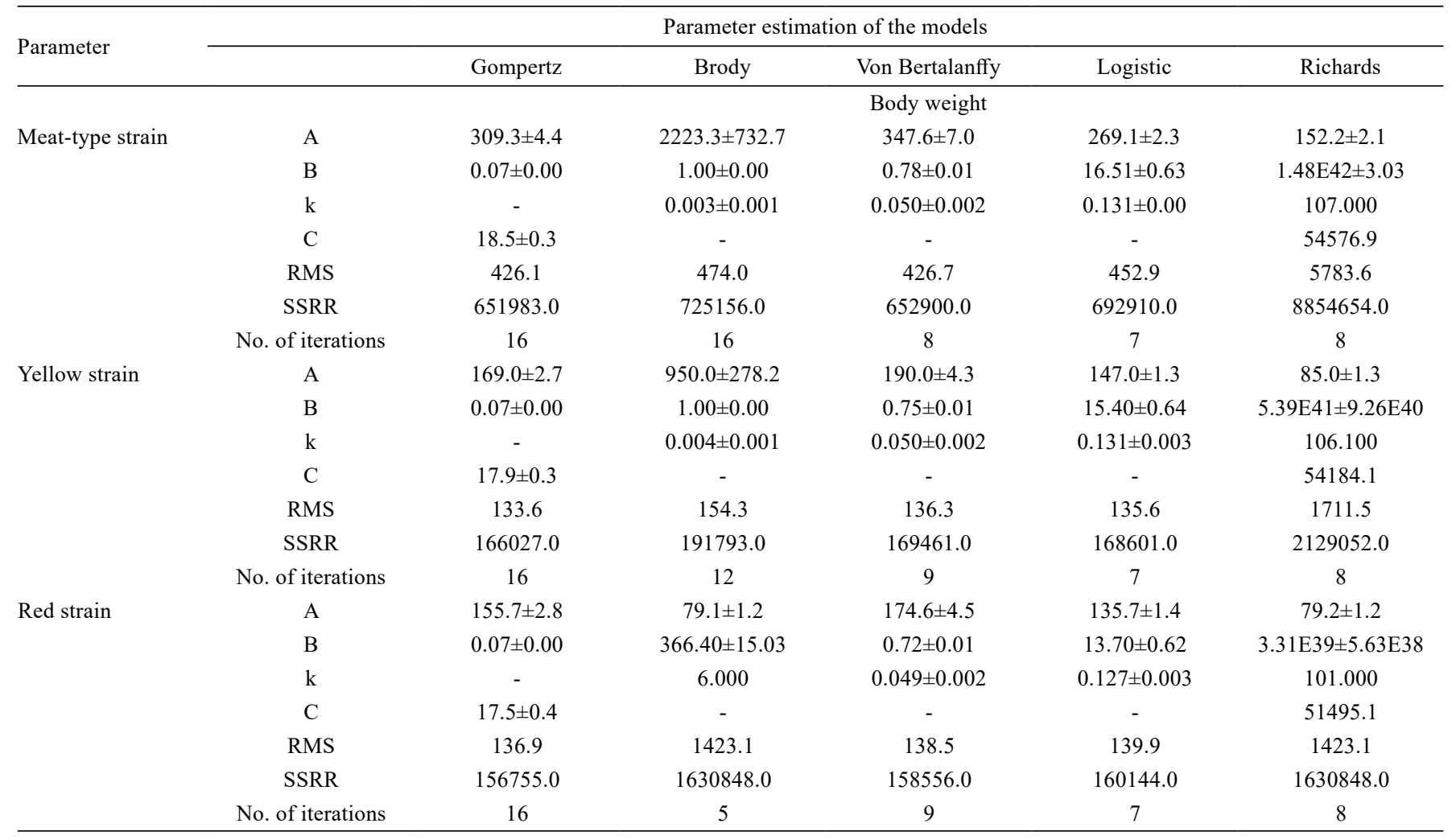

RMS - residual mean square; SSRR - square sum of the regression residual.

For the Brody, von Bertalanffy, Logistic, and Richards models, parameter A (g) is weight at maturity, $\mathrm{k}$ (day ${ }^{-1}$ ) is maturity rate, B is the constant of integration without biological interpretation; for the Richards model, C is the integration constant; for the Gompertz model, A (g) is weight at maturity; B (day ${ }^{-1}$ ) is maturity rate, and C (days) is the time to maximal growth. 
The Brody model did not present a good adjustment to the data for the three quail strains (Table 2).

All the models analyzed adjusted to the data of body chemical composition for the meat-type (Table 3), yellow (Table 4), and red (Table 5) laying quail strains evaluated, but differed in adjustment quality, except for body fat data for which no model could be adjusted.

As for water and body protein, Gompertz was the model that presented the best adjustment for meat-type quail (Figure 2a and 2c, respectively). For body ash, the Logistic model presented a good adjustment for the data; however, Gompertz was better as it presented a lower SSRR (Figure 2e).

In meat-type quail, in the estimation of the parameters using the five models, the Gompertz model produced the highest estimate of parameter A for water, protein, and ashes. The Logistic model gave the highest estimate of maturity rate for water, protein, and ashes $(0.137,0.119$, and 0.111 , respectively), followed by Gompertz (0.083, 0.063 , and 0.047 , respectively). The age at the inflection point of the curve for water, protein, and ash was 15.4, 21.5, and 32.2 days of age, respectively, graphically represented in Figure 2b, 2d and 2f, respectively.

For yellow laying quail, the non-linear models presented convergence and adjustment to the data, but with differences in adjustment quality, for the following variables: water, protein, and body ash (Table 4).

Considering body composition, the Logistic model was better adjusted in yellow laying quail for water, with a RMS difference of 3.65 and an SSRR difference of 102.3 compared with Gompertz, which was the second-best adjustment. For protein and body ash, the Logistic and Gompertz models were the best, with similar results for the number of iterations, RMS, and SSRR, but the Logistic model was best adjusted to the data. For body composition in parameter A, Gompertz had the highest estimates, followed by Logistic, which, for body composition, presented better estimated values for maturity rate (parameter $\mathrm{K}$ ) than Gompertz (parameter B), which presented the second highest estimates. The inflection points of growth rate curves, as described by the Gompertz model that presented good adjustments, were 14.3, 17.7, and 21.0 days of age, respectively, for the variables water, protein, and body ash (Figure 2b, 2d, and 2f, respectively).

All models were adjusted to the data with differences in their adjustment quality.

For water, in red laying quail (Table 5), the best models were the Logistic, due to its low number of iterations (6), RMS (4.40), and SSRR (123.30), followed by Gompertz, which presented the second-best adjustment. For crude

Table 3 - Estimated parameters of non-linear models for body chemical composition in meat-type quail

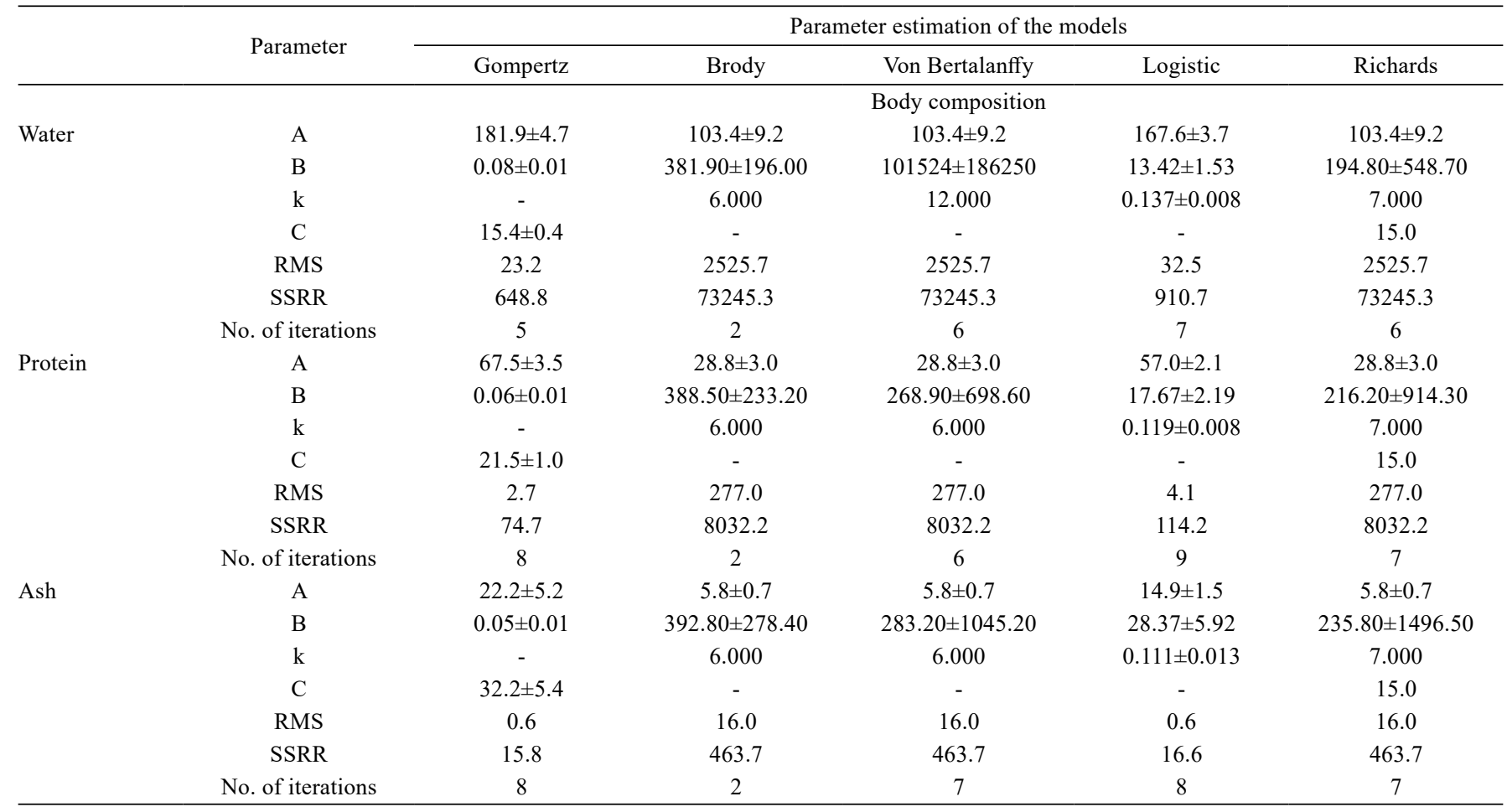

RMS - residual mean square; SSRR - square sum of the regression residual.

For the Brody, von Bertalanffy, Logistic, and Richards models, parameter A (g) is weight at maturity, $\mathrm{k}$ (day ${ }^{-1}$ ) is maturity rate, B is the constant of integration without biological interpretation; for the Richards model, $\mathrm{C}$ is the integration constant; for the Gompertz model, A ( $\mathrm{g}$ ) is weight at maturity; B (day ${ }^{-1}$ ) is maturity rate, and C (days) is the time to maximal growth. 
Table 4 - Estimated values of the non-linear model parameters for body chemical composition in yellow laying quail

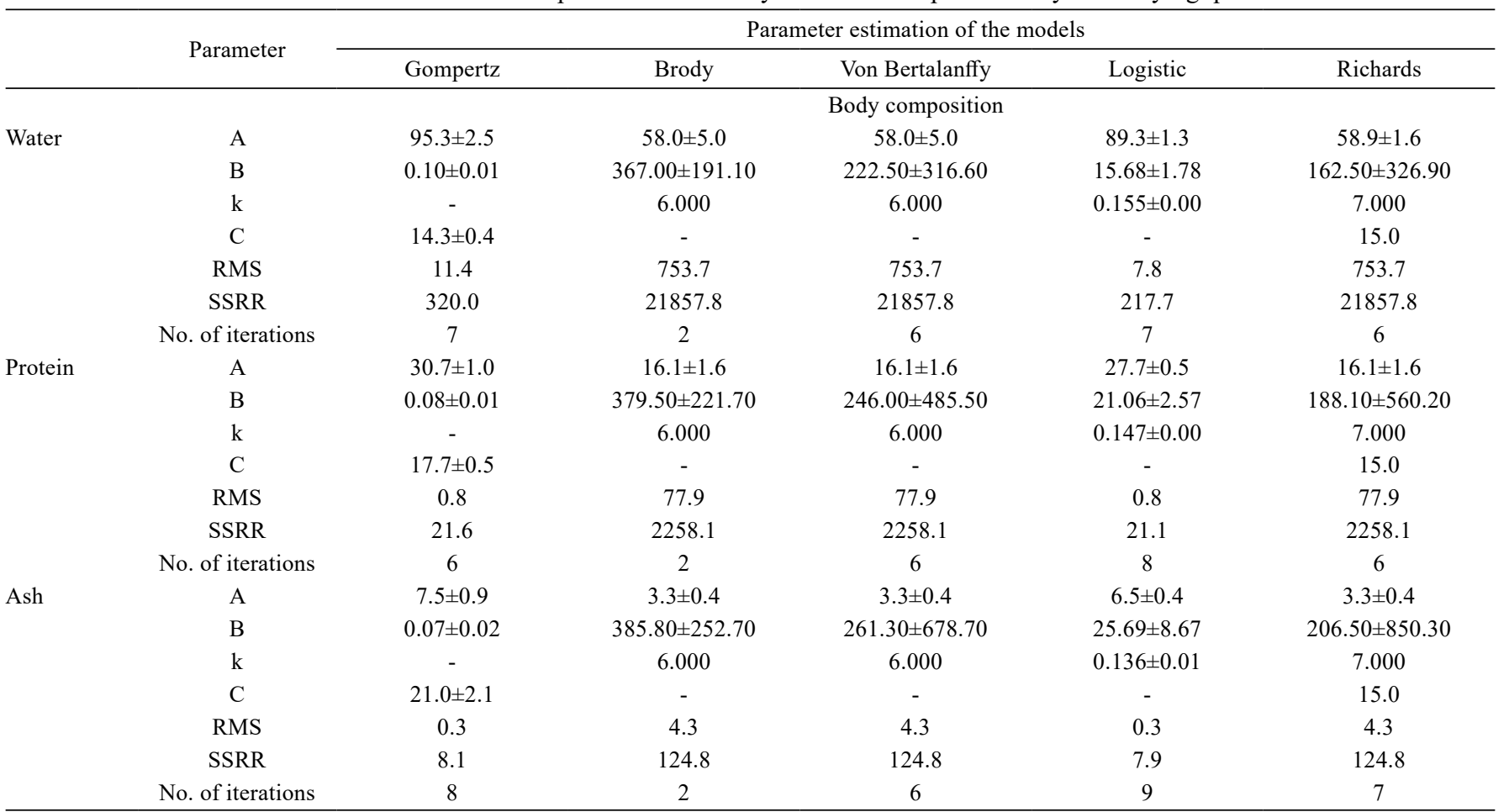

RMS - residual mean square; SSRR - square sum of the regression residual.

For the Brody, von Bertalanffy, Logistic, and Richards models, parameter A (g) is weight at maturity, $\mathrm{k}$ (day ${ }^{-1}$ ) is maturity rate, B is the constant of integration without biological interpretation; for the Richards model, $\mathrm{C}$ is the integration constant; for the Gompertz model, $\mathrm{A}(\mathrm{g})$ is weight at maturity; $\mathrm{B}$ (day ${ }^{-1}$ ) is maturity rate, and $\mathrm{C}$ (days) is the time to maximal growth.

Table 5 - Estimated values of the non-linear model parameters for body chemical composition in red laying quail

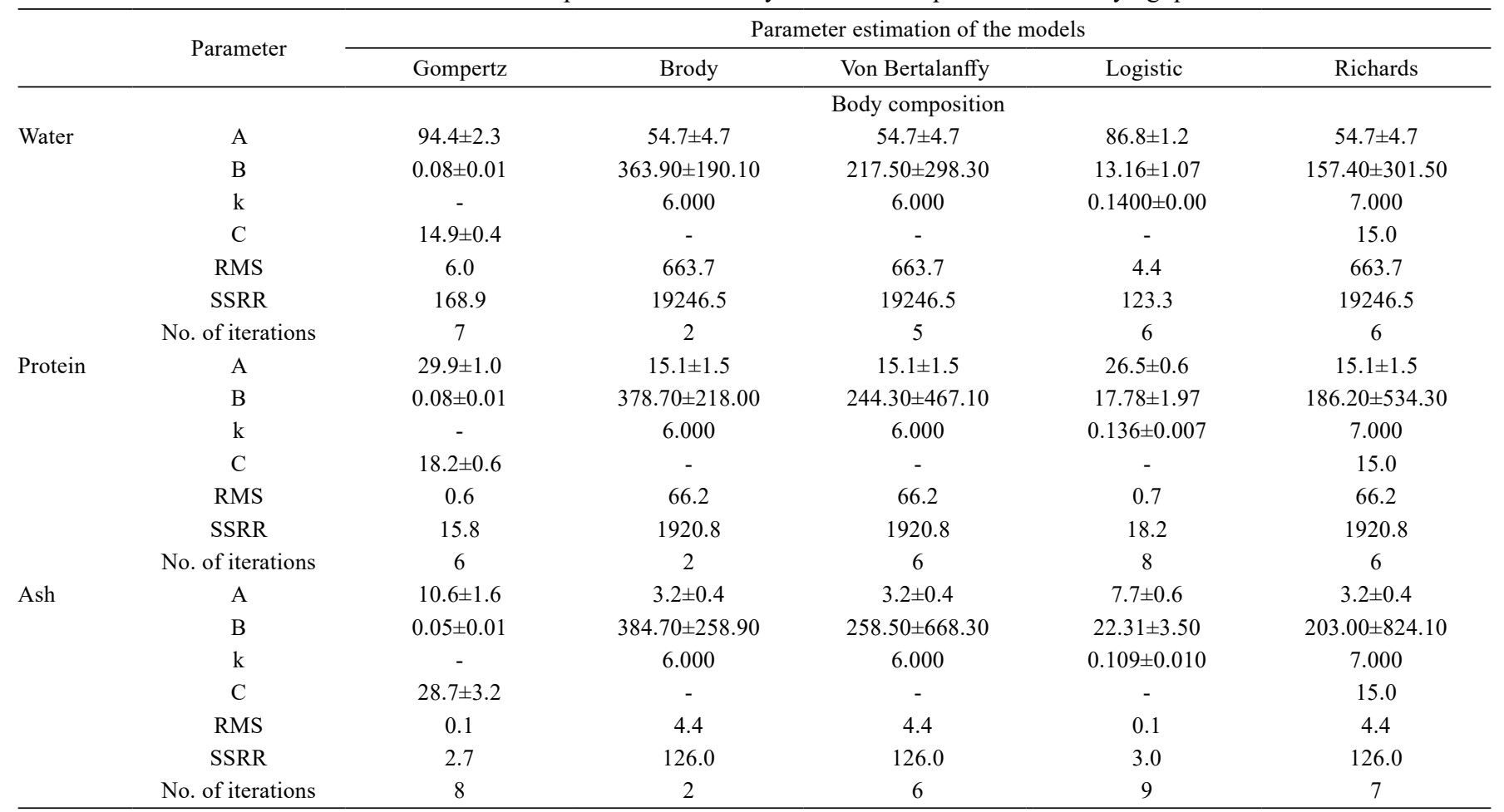

RMS - residual mean square; SSRR - square sum of the regression residual.

For the Brody, von Bertalanffy, Logistic, and Richards models, parameter A (g) is weight at maturity, $\mathrm{k}$ (day ${ }^{-1}$ ) is maturity rate, B is the constant of integration without biological interpretation; for the Richards model, $\mathrm{C}$ is the integration constant; for the Gompertz model, A (g) is weight at maturity; B (day ${ }^{-1}$ ) is maturity rate, and C (days) is the time to maximal growth. 
protein and body ash, Gompertz was best adjusted to the data among evaluated models (Figure 2c and 2e, respectively).

Gompertz also presented the best adjustment for proteins and ash, with the highest and most accurate estimates for parameter A, 29.9 and 10.6. For body water, the Logistic model presented the best adjustment, with the most accurate parameter A estimate of 86.8. Gompertz presented values of $14.9,18.2$, and 28.7 for days of age at which the growth rate was maximum for the variables water, protein, and body ash, respectively (Figure $2 \mathrm{~b}, 2 \mathrm{~d}$, and $2 \mathrm{f}$ ).

The Brody model did not present a good adjustment to the data for body chemical composition, even though it obtained convergence (Tables 3, 4, and 5).

(a)

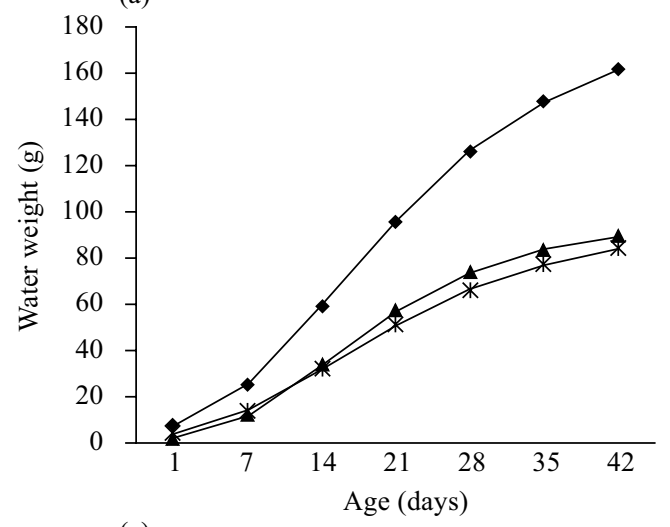

(c)

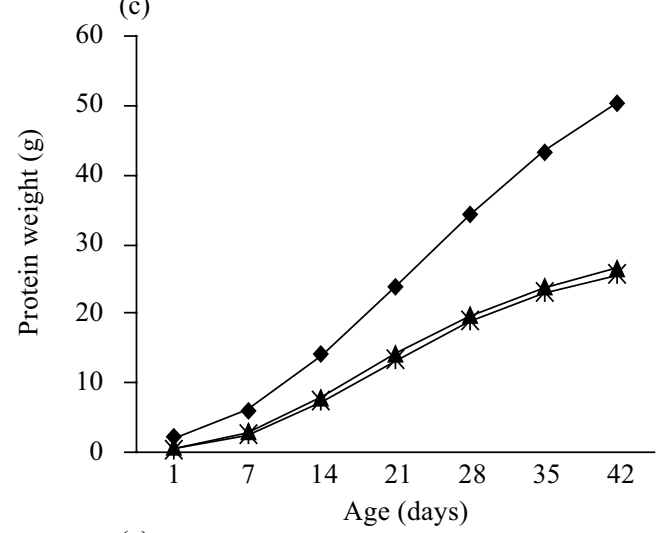

(e)

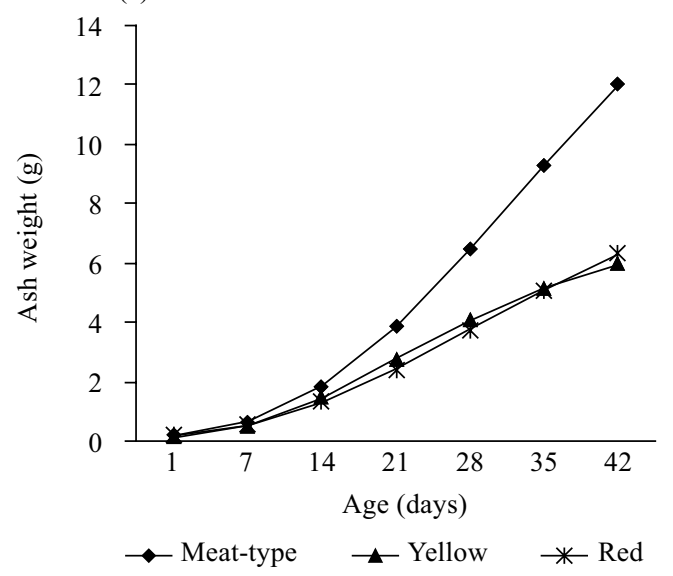

\section{Discussion}

The mean square of residuals, SSRR, and the number of iterations required for the convergence of functions, have commonly been considered (Oliveira et al., 2013) for evaluation of the quality of adjustments to the data of non-linear growth models. The lower the values obtained for these statistical parameters, the better the quality of adjustment of the non-linear model (Tholon and Queiroz, 2009).

A large number of iterations may indicate inappropriate or poorly conditioned models. That is, the smaller the number of iterations, the better the adjustment. However,

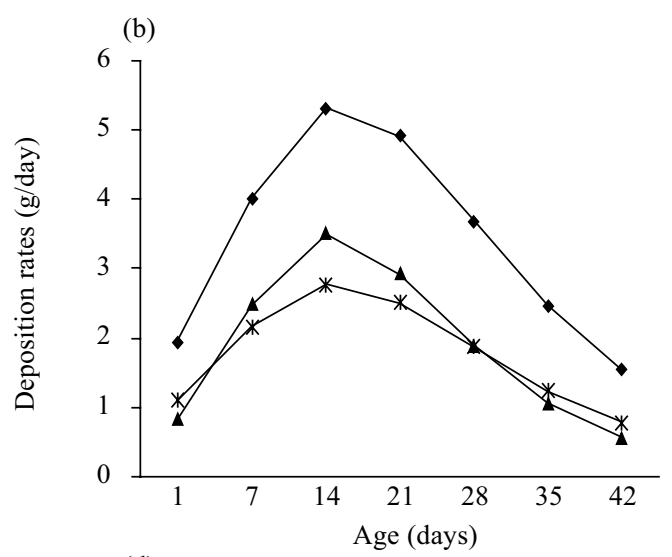

(d)

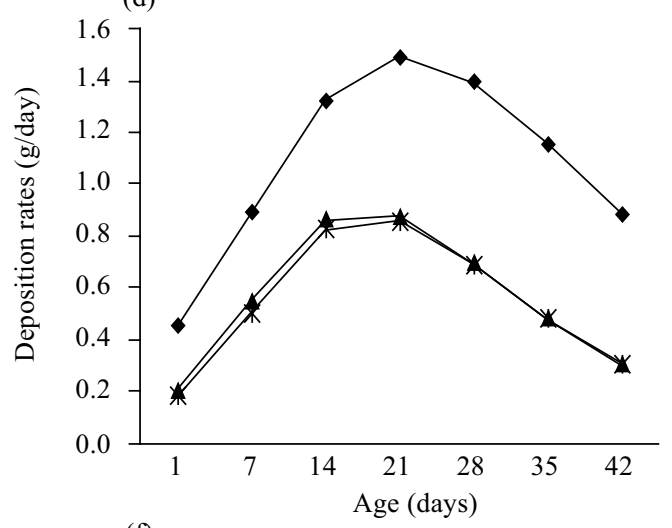

(f)

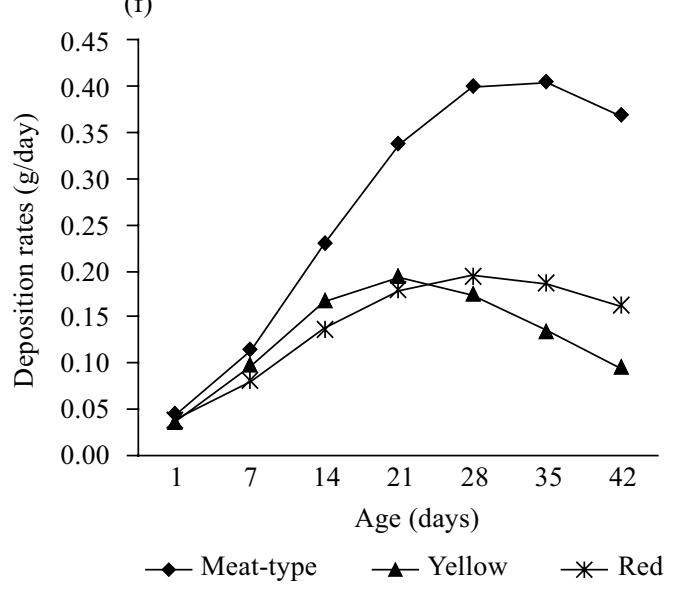

Figure 2 - Growth curves and deposition rates of water (a, b), protein (c, d), and body crude ash (e, f) in meat-type and laying quail (yellow or red). 
Mello et al. (2008) noted that the larger the number of parameters of the model, the greater the possible combinations, requiring higher computational capacity and resulting in a greater number of iterations being required to reach convergence.

Among the non-linear models evaluated, Gompertz was superior to Logistic and Von Bertalanffy, which also presented good adjustment quality for the body weight variable in the three quail lineages. As for body composition, Logistic and Gompertz had the lowest values for RMS and SSRR, in which Gompertz was slightly superior to the Logistic model. Among the evaluated models, Gompertz excelled in terms of data adjustment quality, being the most appropriate to describe the curves for growth and body chemical composition of meat-type and laying quail (yellow and red), in the growth phase.

Results similar to those of the present work were reported by Drumond et al. (2013), in an experiment with three generations of quail from 1 to 42 days old, and among the non-linear models used, the authors concluded that the Gompertz function adequately described the growth of male quail, being a useful tool for the monitoring and evaluation of their growth. Mota et al. (2015) also reported that Gompertz was able to predict growth rate and weight at adulthood of all quail genotypes evaluated, among a total of seven different strains of meat-type and one laying quail strain. In addition to these authors, several others in the literature (Marcato et al., 2010; Narinc et al., 2010; Sakomura et al., 2011; Mazucheli et al., 2011; Grieser et al., 2015b; Rocha-Silva et al., 2016) consider the Gompertz function to be the most adequate for describing growth and deposition of body nutrients in birds.

The Gompertz curve has three parameters, equivalent to a quadratic function. However, it adjusts better to growth curves and can be used over a time interval, allowing estimations to be made for the whole life of the animal. Another advantage of the Gompertz model is that it considers that the initial body mass is greater than zero, which reflects in the fact that the animal is hatched with a certain weight. This model, because of its biological significance, makes it possible to obtain necessary information about the growth of the animals through parameter interpretation (Fialho, 1999).

The weights at maturity estimated by Gompertz for the three strains of quail studied were $309.3,155.7$, and $169.0 \mathrm{~g}$ for the meat-type, red laying, and yellow laying strains, respectively (Table 2). From the means of these values, it can be observed that the meat-type quail, as expected, had a greater genetic potential for weight gain, followed by the yellow and red strains.

Another parameter of the Gompertz model is maturity rate (B) (represented by the letter $\mathrm{K}$ for the other models), associated with time to reach adult weight; thus, the greater the value of the growth rate, the greater the precocity of the animal (Carneiro et al., 2014). In this work, values of 0.07 were estimated for growth rate for both meat-type and laying strains (Table 2), i.e., although they are different genetic strains, they presented similar behavior regarding growth rate. Similar results were reported by Mota et al. (2015), in which different meat-type strains and a laying quail strain presented a value of 0.07 for the estimate of this parameter, in which weight at maturity varied for meat-type strains between 357.50 and $410.50 \mathrm{~g}$, and laying strain presented a value of $166.39 \mathrm{~g}$. The differences seen in the values of weight at maturity may have occurred due to differences in the genetic potential for body growth in the studied strains.

The logistic model presented the highest estimates for maturity rate for the three strains, both for body weight and body composition. Gompertz obtained the second highest estimates for body weight, with all strains having an equal value for parameter B (0.07). As for water, protein, and ash, the meat-type strain presented values of $0.083,0.063$, and 0.047 ; the yellow strain presented values of $0.100,0.084$, and 0.073 ; and the red strain presented values were 0.083 , 0.076 , and 0.050 , respectively. Through these values, it can be observed that the laying strains matured earlier than the meat-type strain, and between the two laying strains, yellow matured earlier for the chemical deposition of water, protein, and ash.

The correlation between parameters weight at maturity and growth rate are high and negative, indicating that animals that have the highest growth rates will achieve their maximum weight at an earlier adult age, being less likely to reach higher adult weight than animals with lower maturity rates and slower growth, which can achieve greater weight at adulthood (Mota et al., 2015).

The Richards model presented difficulties in adjustment and overestimated the values for body weight of the three strains evaluated in this study. It is, therefore, not recommended for describing growth of European and Japanese quail from 1 to 42 days old (Table 2). Different results were reported by Firat et al. (2016), working with Japanese quail from 1 to 42 days of age, which indicated that the Gompertz and Richards models were able to describe body growth of the quail among the non-linear models evaluated (Gompertz, Logistic, and Richards), using a Bayesian approach. 
Kaplan and Gurcan (2016), also recommended the use of the Richards model to describe growth of male and female Japanese quail from 1 to 42 days of age, as it presented the best adjustment to the data among the other non-linear models evaluated (Gompertz, Logistic, Von Bertalanffy, Levakovich, and Janoschek). These differences in the adjustment quality of the models to the data can be attributed to variations in body weight obtained when working with different quail genetics.

The Brody model is also not recommended in this paper to describe growth curve of meat-type and laying quail; this model did not give good fit based on RMS, SSRR, and number of iterations. Mota et al. (2015) also did not recommend this model in their study because growth curve convergence was not obtained with data obtained from birth to 35 days of age in different meat-type and laying quail strains. Likewise, Veloso et al. (2015), analyzing growth of genotypes of free-range chickens, also did not recommended the Brody model.

\section{Conclusions}

Gompertz is the best model for describing growth curves and body chemical composition of body weight, protein, water, and ash in meat-type quail and body weight in yellow laying quail. In addition, Gompertz is the best model for describing growth curves and body chemical composition of body weight, protein, and ash in red laying quail. Logistic is the best model for describing growth curves and body chemical composition of water, protein, and ash in yellow laying quail and the best model for describing growth curves and body chemical composition of water in red laying quail.

\section{Acknowledgments}

The Conselho Nacional de Desenvolvimento Científico e Tecnológico (CNPq; grant no. 425476/2016-2) provided financial support for this project.

\section{References}

AOAC - Association of Official Analytical Chemistry. 2005. Official methods of analysis. 18th ed. Washington, DC, USA.

Barreto, S. L. T.; Quirino, B. J. S.; Brito, C. O.; Umigi, R. T.; Araujo, M. S.; Rocha, T. C. and Pereira, C. G. 2007. Efeitos de níveis nutricionais de energia sobre o desempenho e a qualidade de ovos de codornas europeias na fase inicial de postura. Revista Brasileira de Zootecnia 36:86-93. https://doi.org/10.1590/S151635982007000100011

Brody, S. 1945. Bioenergetics and growth. Reinhold Publishing Corp., New York. 1023p.
Carneiro, A. P. S.; Muniz, J. A.; Carneiro, P. L. S.; Malhado, C. H. M.; Martins Filho, R. and Silva, F. F. 2014. Identidade de modelos não lineares para comparar curvas de crescimento de bovinos da raça Tabapuã. Pesquisa Agropecuária Brasileira 49:57-62.

Drumond, E. S. C.; Gonçalves, F. M.; Veloso, R. C.; Amaral, J. M.; Balotin, L. V.; Pires, A. V. and Moreira, J. 2013. Curvas de crescimento para codornas de corte. Ciência Rural 43:1872-1877. https://doi.org/10.1590/S0103-84782013001000023

Fialho, F. B. 1999. Interpretação da curva de crescimento de Gompertz. Empresa Brasileira de Pesquisa Agropecuária - EMBRAPA/ CNPSA, Concórdia.

Finco, E. M.; Marcato, S. M.; Furlan, A. C.; Rossi, R. M.; Grieser, D. O.; Zancanela V.; Oliveira, T. M. M. and Stanquevis, C. E. 2016. Adjustment of four growth models through Bayesian inference on weight and body nutrient depositions in laying quail. Revista Brasileira de Zootecnia 45:737-744. https://doi.org/10.1590/ s1806-92902016001200002

Firat, M. Z.; Karaman, E.; Başar, E. K. and Narinc, D. 2016. Bayesian analysis for the comparison of nonlinear regression model parameters: an application to the growth of Japanese quail. Revista Brasileira de Ciência Avícola 18(no spe):19-26. https:// doi.org/10.1590/1806-9061-2015-0066

Fitzhugh Jr., H. A. 1976. Analysis of growth curves and strategies for altering their shape. Journal of Animal Science 42:1036-1051. https://doi.org/10.2527/jas1976.4241036x

Freitas, A. R. 2005. Growth curves in animal production. Revista Brasileira de Zootecnia 34:786-795. https://doi.org/10.1590/ S1516-35982005000300010

Grieser, D. O.; Marcato, S. M.; Furlan, A. C.; Zancanela, V.; Batista, E.; Ton, A. P. S.; Perine, T. P. and Stanquevis, C. E. $2015 \mathrm{a}$. Desempenho e rendimento de carcaça e partes de três diferentes linhagens de codornas. Zootecnia Tropical 33:61-72.

Grieser, D. O.; Marcato, S. M.; Furlan, A. C.; Zancanela, Z.; Ton, A. P. S.; Batista, E.; Perine, T. P.; Pozza, P. C. and Sakomura, N. C. 2015b. Comparison of growth curve parameters of organs and body components in meat- (Coturnix coturnix coturnix) and laying-type (Coturnix coturnix japonica) quail show interactions between gender and genotype. British Poultry Science 56:6-14. https://doi.org/10.1080/00071668.2014.988602

Kaplan, S. and Gürcan, E. K. 2016. Comparison of growth curves using non-linear regression function in Japanese quail. Journal of Applied Animal Research 1:1-6.

Marcato, S. M.; Sakomura, N. K.; Fernandes, J. B. K.; Siqueira, J. C.; Dourado, L. R. B. and Freitas, E. R. 2010. Growth and nutrients deposition on organs of two commercial strains of broiler chickens. Revista Brasileira de Zootecnia 39:1082-1091. https://doi.org/10.1590/S1516-35982010000500019

Mazucheli, J.; Souza, R. M. and Philippsen, A. S. 2011. Gompertz growth model in the presence of normal errors heteroscedastic: a case study. Biometric Brazilian Journal 29:91-101.

Mello, R.; Magalhães, A. L. R.; Breda, F. C. and Regazzi, A. J. 2008. Models for fit of gas production in sunflower and corn silages. Pesquisa Agropecuária Brasileira 43:261-269. https://doi. org/10.1590/S0100-204X2008000200016

Mota, L. F. M.; Alcântara, D. C.; Abreu, L. R. A; Costa, L. S.; Pires, A. V.; Bonafé, C. M.; Silva, M. A. and Pinheiro, S. R. F. 2015. Growth comparison of different genetic groups using nonlinear models. Arquivo Brasileiro de Medicina Veterinária e Zootecnia 67:1372-1380. https://doi.org/10.1590/1678-4162-7534

Narinc, D.; Karaman, E.; Firat, M. Z. and Aksoy, T. 2010. Comparison of non-linear growth models to describe the growth in Japanese quail. Journal of Animal and Veterinary Advances 9:1961-1966. https://doi.org/10.3923/javaa.2010.1961.1966

Nelder, J. A. 1961. The fitting of a generalization of the logistic curve. Biometrics 17:89-110. 
Oliveira, A. M. S.; Oliveira, C. A. L.; Matsubara, B. J. A.; Oliveira, S. N.; Kunita, N. M.; Yoshida, G. M. and Ribeiro, R. P. 2013. Growth patterns of male and female of Nile tilápia (Oreochromis niloticus) GIFT variety. Semina: Ciências Agrárias 34:1891-1900. https://doi.org/10.5433/1679-0359.2013v34n4p1891

Richards, F. J. 1959. A flexible growth function for empirical use. Journal of Experimental Botanic 10:290-300.

Rocha-Silva, M.; Araujo, C. V.; Pires, A. V.; De Paula, E. J. H.; Ferreira, E. B. and Da Silva, F. G. 2016. Curva de crescimento de codornas de corte por meio de modelos de regressão não-lineares. Archives of Veterinary Science 21:26-34. https://doi.org/10.5380/ avs.v21i4.41571

Rossi, R. M.; Grieser, D. O.; Conselvan, V. A. and Marcato, S. M. 2017. Growth curves in meat-type and laying quail: a Bayesian perspective. Semina: Ciências Agrárias 38:2743-2754. https://doi. org/10.5433/1679-0359.2017v38n4Sup11p2743

Rostagno, H. S.; Albino, L. F. T.; Hannas, M. I.; Donzele, J. L.; Sakomura, N. K.; Perazzo, F. G.; Saraiva, A.; Abreu, M. L. T.; Rodrigues, P. B.; Oliveira, R. F.; Barreto, S. L. T. and Brito, C. O. 2017. Tabelas brasileiras para aves e suínos: composição de alimentos e exigências nutricionais. 4 ed. UFV, Viçosa, MG.

Sakomura, N. K.; Gous, R. M.; Marcato, S. M. and Fernandes, J. B. K. 2011. A descrition of the growth of major body components of 2 broiler chicken strains. Poultry Science 90:2888-2896. https://doi.org/10.3382/ps.2011-01602

Sakomura, N. K. and Rostagno, H. S. 2016. Métodos de pesquisa em nutrição de monogástricos. 2 ed. Funep, Jaboticabal, SP.

Tholon, P. and Queiroz, S. A. 2009. Mathematic models applied to describe growth curves in poultry applied to animal breeding. Ciência Rural 39:2261-2269. https://doi.org/10.1590/S010384782009000700050

Veloso, R. C.; Pires, A. V.; Torres Filho, R. A.; Drumond, E. C. S.; Costa, L. S.; Amaral, J. M. and Pereira, I. G. 2015. Growth of genotypes of an alternative strain of broiler chickens. Arquivo Brasileiro de Medicina Veterinária e Zootecnia 67:1361-1371. https://doi.org/10.1590/1678-4162-6816

Von Bertalanffy, L. 1957. Quantitative laws in metabolism and growth. The Quarterly Review of Biology 32:217-230. 